\title{
Determination of the structural characteristics in youngsters from Ceará with Class II, division 1 malocclusion
}

Keila Maria de Sousa Castelo1, Fausto Silva Bramante²

Objective: To determine the structural characteristics of Caucasian youths from Ceará State, Northeastern Brazil, presenting with Class II, Division 1 malocclusion and to investigate whether there is gender dimorphism based on the cephalometric variables assessed.

Methods: By means of lateral cephalograms, it was possible to determine the cephalometric characteristics of Class II, Division 1 malocclusion in a sample of 50 Caucasian youths from Ceará State, Brazil, of both genders (25 male and 25 female), aged between 9 and 14 years, who had not received previous orthodontic treatment. Sixteen cephalometric measures were evaluated and a comparison was made between the experimental group (Class II) and the control group (Class I), a sample comprising 50 Caucasian children from the Brazilian State of Ceará, of both genders (22 male and 28 female), aged 9 to 13 years, obtained from research conducted at the Study Center of the Federal University of Ceará (UCCB), Department of Orthodontics.

Conclusions: Overall, the maxilla exhibited adequate positioning. The mandible showed a clear predominance of retrusion and dimensional changes in the sagittal direction. The facial vertical dimensions were increased. The maxillary incisors were well-positioned in their apical bases and with slight lingual inclination. The mandibular incisors were labially inclined and protruded. The study identified the presence of gender dimorphism in the following measures: P-Nperp, Co-A, Wits and ALFH.

Keywords: Angle Class II malocclusion. Cranial circumference. Orthodontics.

${ }^{1}$ MSc in Orthodontics, Maranhão University.

${ }^{2} \mathrm{PhD}$. in Orthodontics, Bauru School of Dentistry. Professor of the Graduation Program in Dentistry, Area of concentration Orthodontics, Maranhão University.
How to cite this article: Castelo KMS, Bramante FS. Determination of the structural characteristics in youngsters from Ceará with Class II, division 1 malocclusion. Dental Press J Orthod. 2012 July-Aug;17(4):140-7.

Submitted: April 8, de 2010 - Revised and accepted: September 18, 2011

" The authors report no commercial, proprietary or financial interest in the products or companies described in this article.

Contact address: Keila Maria de Sousa Castelo

Rua Senador Paula Pessoa, 837 - Lago Jacarey - Fortaleza/CE, Brazil

CEP: 60822-200 - Email: keilacastelo@hotmail.com 


\section{Determinação das características estruturais em jovens do Ceará com má oclusão de Classe II, divisão 1}

Keila Maria de Sousa Castelo', Fausto Silva Bramante²

Objetivo: determinar as características estruturais em jovens cearenses leucodermas, portadores de má oclusão de Classe II, divisão 1, e verificar se existe dimorfismo entre os sexos a partir das variáveis cefalométricas estudadas.

Métodos: por meio de telerradiografias em norma lateral, determinou-se as características cefalométricas da má oclusão de Classe II, divisão 1, em uma amostra de 50 jovens cearenses, leucodermas, sendo 25 do sexo masculino e 25 do sexo feminino, com idades de 9 a 14 anos, não tratadas ortodonticamente. Dezesseis grandezas cefalométricas foram avaliadas, comparando-se o grupo experimental (Classe II) com um grupo controle (Classe I), cuja amostra constituiu-se de 50 crianças do Ceará, leucodermas, de ambos os sexos (22 do sexo masculino e 28 do sexo feminino), com idades entre 9 e 13 anos, obtida de pesquisas realizadas pela disciplina de Ortodontia da UCCB - Centro de Estudos da Universidade Federal do Ceará.

Conclusão: a maxila apresentou, em média, um bom posicionamento. A mandíbula apresentou uma clara predominância para retrusão e alterações dimensionais no sentido sagital. As dimensões verticais da face apresentaram-se aumentadas. Os incisivos superiores apresentaram-se bem posicionados em suas bases apicais e ligeiramente inclinados para lingual. Os incisivos inferiores protruídos e inclinados para vestibular. Identificou-se a presença de dimorfismo entre os sexos nas grandezas P-Nperp, Co-A, WITS e AFAI.

Palavras-chave: Má oclusão de Angle Classe II. Circunferência craniana. Ortodontia.

${ }^{1}$ Especialista e Mestre em Ortodontia pelo Centro Universitário do Maranhão (Uniceuma).

${ }^{2}$ Mestre e Doutor em Ortodontia pela FOB-USP. Professor do programa de Pós-graduação em Odontologia, área de concentração Ortodontia, no Uniceuma.
Como citar este artigo: Castelo KMS, Bramante FS. Determination of the structural characteristics in youngsters from Ceará with Class II, division 1 malocclusion. Dental Press J Orthod. 2012 July-Aug;17(4):140-7.

Enviado em: 08 de abril de 2010 - Revisado e aceito: 18 de setembro de 2011

» A autora declara não ter interesses associativos, comerciais, de propriedade ou financeiros, que representem conflito de interesse nos produtos e companhias descritos nesse artigo.

Endereço para correspondência: Keila Maria de Sousa Castelo Rua Senador Paula Pessoa, 837 - Lago Jacarey - CEP: 60822-200 - Fortaleza/CE Email: keilacastelo@hotmail.com 


\section{INTRODUCTION}

With the purpose of establishing scientific standards for different racial groups, dentofacial behavior studies have been conducted by researchers in various ethnic groups. Current cephalometric standards do not apply to all individuals given the wide range of racial and miscigenation characteristics. ${ }^{2}$

Comparative cephalometric evaluations showed indeed the existence of differences in craniofacial morphology between different racial groups. ${ }^{15}$ The ethnic background of Ceará State's population comprise a miscegenation of Portuguese and Indians (indigenous population), resulting in a facial pattern that differs from other populations. This population can be identified as a group with facial and skeletal features that represent a particular morphological pattern: the brachycephalic. ${ }^{10}$

In this context and in light of the proven variability, research was carried out to determine the skeletal and dental characteristics of Class II, Division 1 malocclusion, present in $22.3 \%$ of Ceará youths. ${ }^{10}$ Knowledge of this population characteristics is of utmost importance, since, due to geographic and economic difficulties, a wide emigration process occurs from that region to more developed and therefore more attractive ones, not only inside Brazil but also to other countries. Evaluation of the cephalometric characteristics of Class II, Division 1 malocclusion was performed in a sample of 50 Caucasian Ceará youths, which ultimately provided further information about the dentoskeletal patterns of this racial group.

\section{MATERIAL AND METHODS}

The sample for the experimental group consisted of 50 lateral cephalograms of Caucasian Ceará youths of both genders (25 male and 25 female) aged between 9 and 14 years presenting with Class II, Division 1 malocclusion, originated from a private file comprising 5,000 orthodontic records.

The following selection criteria were used for inclusion of individuals in the experimental group: dental casts displaying increased overjet, $1 / 2$ Class II, $3 / 4$ Class II and full Class II molar relationship, ANB angle of $4.5^{\circ}$ or greater with no history of previous orthodontic treatment and radiographs taken using the same equipment.
The control group consisted of 50 lateral cephalograms of Ceará youths (22 male and 28 female) aged between 9 and 13 years, all with normal occlusion (molar and canine Class I), displaying facial harmony in frontal and lateral views, normal overbite, dental irregularities, if present, did not surpass $3 \mathrm{~mm}$, overjet of $3 \mathrm{~mm}$ or lower, and no previous orthodontic treatment.

After selecting the lateral cephalometric radiographs the images were scanned. Thereafter, these images were imported into the Cef-X software (CDT software, version 2.1.24). The patients were registered and points of interest marked following the guidelines provided by the software.

The anatomical points (landmarks) were marked, resulting in the angular and linear cephalometric measures of interest, following the specifications of Downs, ${ }^{5}$ Riedel, ${ }^{15}$ Steiner and Riedel, ${ }^{24}$ Jacobson ${ }^{6}$ and McNamara Jr." The lines and planes that compose the skeletal and dental cephalometric variables used in the study are shown in Figures 1 and 2. The linear and angular measures used for the control and experimental groups were: SNA, SNB, ANB, SNGoGn, 1.NA, 1-NA, 1.NB, 1-NB, Co-A, Co-Gn, ALFH, DMM, A-Nperp, P-Nperp, Wits and HF.PM. The values of the experimental group were compared to the control group's values and the statistical test applied.

\section{Method error}

In order to determine the results' reliability a second measurement was performed on all cephalometric radiographs after a 30 days interval by the same subject. The systematic and random errors (Dahlberg and $t$ test respectively) were applied to each cephalometric measure.

\section{Statistical Analysis}

After registering the cephalometric measurements a normality test (Shapiro-Wilk) was performed. Since variables ANB and ALFH had a $p$ value lower than 0.05 , they were analyzed by the nonparametric Wilcoxon test. To test compatibility between groups regarding age as well as the mean and standard deviation values of the cephalometric variables, Student's $t$ test was applied. A significance level of $\mathrm{p}<0.05$ was adopted. To check for the existence of gender dimorphism Student's independent $t$ test was applied. 


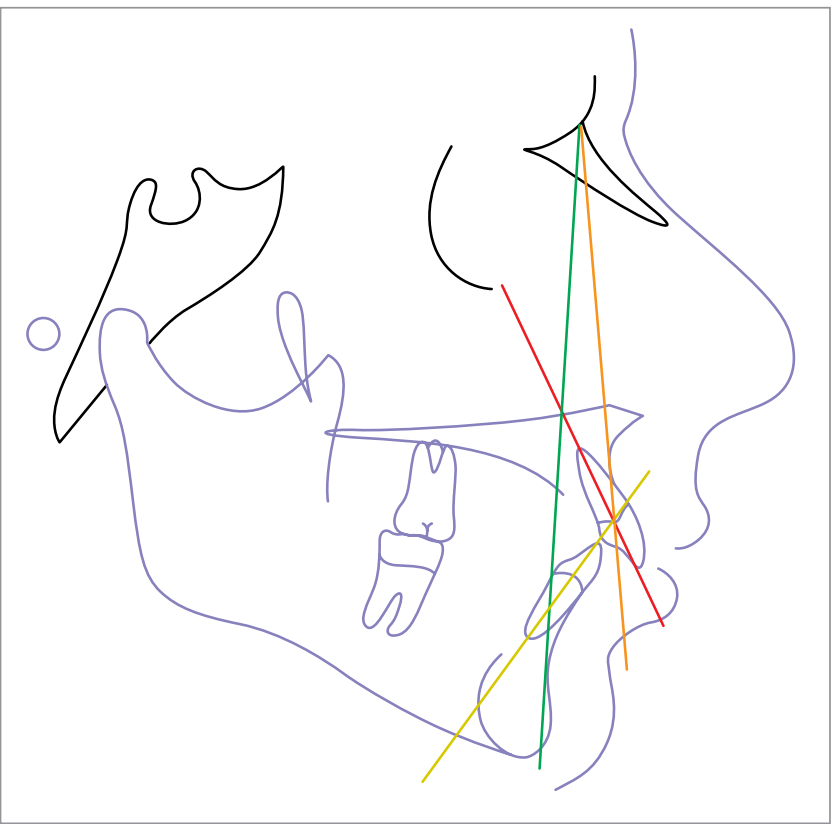

Figure 1 - Skeletal cephalometric variables, according to Dows, Riedel, Steiner and Riedel, Jacobson, McNamara Jr.

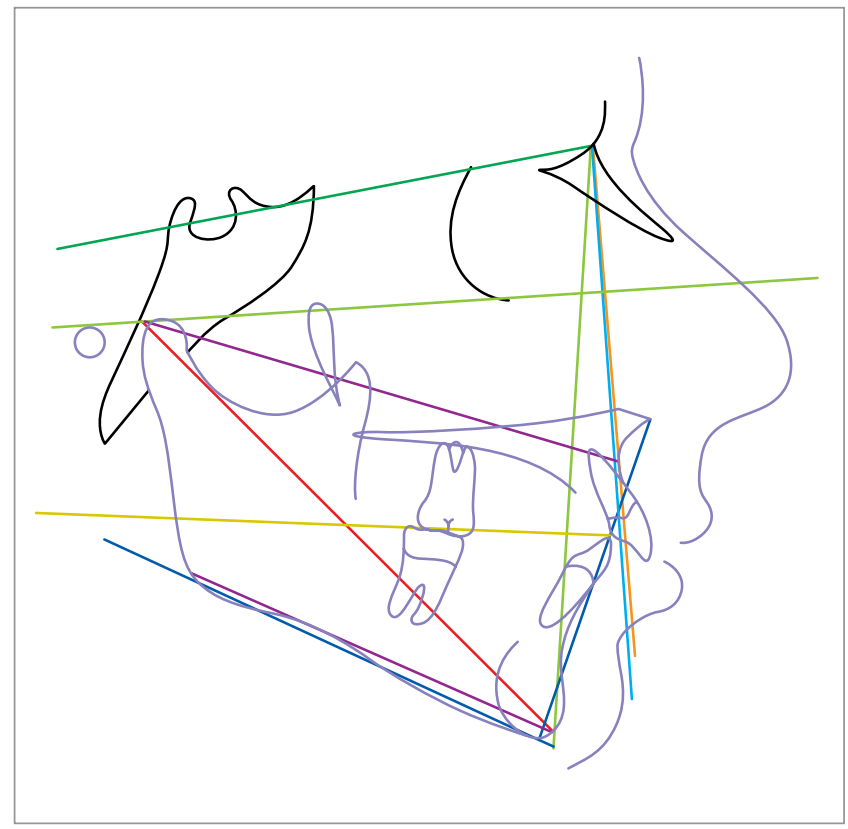

Figure 2 - Dental cephalometric variables according to Steiner and, also, Steiner and Riedel.

\section{RESULTS}

The data in Table 1 show normal distribution for 14 of the 16 measures assessed. According to the Wilcoxon data in Table 2, ANB showed no significant pre/ post difference $(p>0.05)$. Variable ALFH showed significant pre/post difference $(\mathrm{p}<0.05)$. The data presented in Table 3 show the two measurements taken with a 30 day interval, displaying the means and standard deviations of the paired $t$ test and the random error. Among the 16 variables studied, only one exhibited systematic error (bias): ALFH.

Comparison between genders showed that four measures had statistically significant differences (Tab 4). Table 5 presents a comparison between the experimental and control groups.

\section{DISCUSSION}

In assessing gender dimorphism in the experimental group only four measures displayed statistically significant differences. All differences between variables were found in linear measures: Co-A, PNperp, Wits and ALFH. These results are consistent with a study which found that only linear measurements show significant differences between genders in Class II, Division 1 malocclusions. ${ }^{5}$ Silva Filho et $\mathrm{a}^{23}$ found that the behavior of angular cephalometric measures in Class II, Division 1, Pattern II malocclusion is independent of the gender variable.

The sagittal position of the maxilla (SNA) displayed similarity between the experimental and the control groups, revealing to be well positioned in relation to the skull base. This finding is confirmed by most published works. ${ }^{1,4,9,13,16,20,22}$ Some researchers support the idea that changes in the respiratory function may lead the soft tissues of the face to increase in length. These tissues can inhibit the forward development of the nasomaxillary complex, maintaining the maxilla in a good position. ${ }^{24}$ Measured linearly, the maxilla was found to be in a protruded position. This mismatch between the SNA angle and A-Nperp values can be explained by the difficulty in locating some landmarks related to the Frankfurt plane, such as Condylion and Orbitale. Potential changes in the inclination of the aforesaid plane, resulting from the above mentioned difficulties would imply changes in the A-Nperp measurement. ${ }^{22}$

Analysis of mandiblar position assessed by SNB angle showed that the mandibular retrusion in 
Table 1 - Shapiro-Wilk test.

\begin{tabular}{|c|c|c|}
\hline VARIABLES & $\mathbf{W}$ & $\mathbf{P}$ \\
\hline Age 1 & 0.96 & 0.24 \\
\hline Age 2 & 0.96 & 0.24 \\
\hline \multicolumn{3}{|c|}{ CEPHALOMETRICS } \\
\hline SNA 1 & 0.98 & 0.72 \\
\hline SNA 2 & 0.98 & 0.77 \\
\hline SNB 1 & 0.98 & 0.90 \\
\hline SNB 2 & 0.98 & 0.86 \\
\hline ANB 1 & 0.88 & 0.00 \\
\hline ANB2 & 0.88 & 0.00 \\
\hline A-Nperp 1 & 0.98 & 0.77 \\
\hline A-Nperp 2 & 0.97 & 0.63 \\
\hline P-Nperp 1 & 0.95 & 0.10 \\
\hline P-Nperp 2 & 0.94 & 0.05 \\
\hline Co-A 1 & 0.98 & 0.91 \\
\hline Co-A 2 & 0.98 & 0.92 \\
\hline Co-Gn 1 & 0.97 & 0.65 \\
\hline Co-Gn 2 & 0.97 & 0.49 \\
\hline DMM 1 & 0.97 & 0.70 \\
\hline DMM 2 & 0.97 & 0.61 \\
\hline SNGoGn 1 & 0.97 & 0.50 \\
\hline SNGoGn 2 & 0.95 & 0.19 \\
\hline AFAI 1 & 0.94 & 0.04 \\
\hline AFAI 2 & 0.96 & 0.02 \\
\hline 1-NA 1 & 0.97 & 0.44 \\
\hline 1-NA 2 & 0.97 & 0.44 \\
\hline 1.NA 1 & 0.98 & 0.84 \\
\hline 1.NA 2 & 0.98 & 0.92 \\
\hline 1-NB 1 & 0.94 & 0.06 \\
\hline 1-NB 2 & 0.95 & 0.07 \\
\hline 1.NB 1 & 0.97 & 0.46 \\
\hline 1.NB 2 & 0.96 & 0.39 \\
\hline HF.PM 1 & 0.97 & 0.62 \\
\hline HF.PM 2 & 0.97 & 0.67 \\
\hline
\end{tabular}

Table 2 - Wilcoxon test.

\begin{tabular}{ccccc} 
& ANB Pre & ANB Post & AFAl Pre & AFAl Post \\
\hline Median & 6.40 & 6.55 & 70.87 & 70.64 \\
Z & & 0.71 & & 2.33 \\
$\mathrm{p}$ & 0.47 & 0.01 \\
\hline
\end{tabular}

relation to the skull base. This is a frequent finding in other studies. ${ }^{1,4,9,13,16,22,26}$ Some researchers have suggested that this is partly due to the skull base architecture, specifically the Basion-Sella-Nasion angle, which under genetic influence appears more obtuse, favoring a more posterior positioning of the mandible and thereby generating a poor relationship between the basal bones. ${ }^{15}$ Evaluation by means of linear measurements showed that the mandible was in a retruded position. This result was found by most studies in the literature. ${ }^{1,11,16,22}$

To verify the maxillo-mandibular relationship the angular measure ANB and the linear measure Wits were employed. The degree of sagittal discrepancy observed by means of the angular measure suggests a spacial disharmony between the apical bases. An increase in this angle was also observed in studies by Santos. ${ }^{22}$ The discrepancy observed by means of the linear measure AO-BO (Wits) also points to a basal disharmony. Canuto ${ }^{3}$ observed that the higher the $\mathrm{ANB}$, the greater the $\mathrm{AO}-\mathrm{BO}$ distance, i.e., he found a positive correlation between ANB and Wits.

Proportionality between the skeletal components was evaluated according to the principles advocated by McNamara. ${ }^{12}$ The effective length of the maxilla (Co-A) showed a statistically significant difference when compared to the control group sample, revealing an increased maxilla, and corroborating with a previous study. ${ }^{19}$ The mandiblar length (Co-Gn) showed a reduced size, which does not differ from the findings of most researchers. ${ }^{8,13,22}$ The variable DMM exhibited an unfavorable maxillomandibular relationship, although it did not show statistically significant difference when compared to the control group sample. This can be explained by the fact that DMM is part of a set of measures involving proportionality and this aspect must therefore be taken into account. The anterior lower facial height (ALFH) displayed increased vertical dimension. McNamara ${ }^{11}$ posited that excessive vertical development in these individuals is a frequent feature and can be a manifestation of changes in respiratory function. Maia ${ }^{9}$ argued that this increase in ALFH occurs due to a more vertical facial growth pattern. Most patients in the experimental group had no lip competence, possibly due to a discrepancy between the jaws (retruded and smaller mandibles). One cannot assert in this study that the patients had a 
Table 3 - Means and standard deviations of Student's paired $t$ test and random error for the two measurements taken.

\begin{tabular}{|c|c|c|c|c|c|c|c|c|}
\hline \multirow{2}{*}{ VARIABLES } & \multicolumn{2}{|c|}{$1^{\text {st }}$ MEASUREMENT } & \multicolumn{2}{|c|}{$2^{\text {nd }}$ MEASUREMENT } & \multirow{2}{*}{$\mathbf{N}$} & \multirow{2}{*}{ DAHLBERG } & \multirow{2}{*}{$\boldsymbol{t}$} & \multirow{2}{*}{$\mathbf{P}$} \\
\hline & Mean & SD & Mean & SD & & & & \\
\hline \multicolumn{9}{|c|}{ MAXILLARY COMPONENT } \\
\hline SNA $\left(^{\circ}\right)$ & 83.82 & 3.11 & 83.86 & 3.10 & 50 & 1.16 & -0.18 & 0.858 \\
\hline Co-A (mm) & 99.35 & 5.32 & 99.26 & 5.34 & 50 & 2.88 & -0.27 & 0.782 \\
\hline A-Nperp (mm) & 3.61 & 2.99 & 3.67 & 3.02 & 50 & 1.52 & -0.24 & 0.810 \\
\hline \multicolumn{9}{|c|}{ MANDIBULAR COMPONENT } \\
\hline SNB $\left(^{\circ}\right)$ & 76.73 & 2.89 & 77.6 & 3.14 & 50 & 0.84 & -0.12 & 0.898 \\
\hline Co-Gn (mm) & 120.86 & 6.69 & 117.9 & 12.02 & 50 & 9.18 & 0.35 & 0.722 \\
\hline P-Nperp (mm) & -6.4 & 5.59 & 0.98 & 24.9 & 50 & 3.18 & -0.42 & 0.670 \\
\hline \multicolumn{9}{|c|}{ MAXILLO-MANDIBULAR RELATIONSHIP } \\
\hline $\operatorname{ANB}\left({ }^{\circ}\right)$ & 6.59 & 1.79 & 6.75 & 1.73 & 50 & 0.45 & -0.18 & 0.852 \\
\hline Wits (mm) & 6.41 & 2.84 & 6.43 & 2.73 & 50 & 0.02 & -0.34 & 0.576 \\
\hline $\mathrm{DMM}(\mathrm{mm})$ & 21.85 & 3.82 & 21.73 & 3.81 & 50 & 4.20 & 0.29 & 0.766 \\
\hline \multicolumn{9}{|c|}{ VERTICAL COMPONENT } \\
\hline SN.GoGn $\left(^{\circ}\right)$ & 33.34 & 4.54 & 33.46 & 4.67 & 50 & 1.35 & -0.51 & 0.605 \\
\hline HF. PM $\left(^{\circ}\right)$ & 25.75 & 4.10 & 25.84 & 4.04 & 50 & 3.61 & 0.43 & 0.664 \\
\hline AFAI (mm) & 71.02 & 4.75 & 70.38 & 4.60 & 50 & 1.56 & 0.00 & $0.009^{\star}$ \\
\hline \multicolumn{9}{|c|}{ DENTOALVEOLAR COMPONENT } \\
\hline 1.NA( $\left(^{\circ}\right)$ & 22.68 & 8.6 & 21.90 & 8.62 & 50 & 11.80 & -0.32 & 0.747 \\
\hline $1-\mathrm{NA}(\mathrm{mm})$ & 4.47 & 2.85 & 3.63 & 2.77 & 50 & 0.83 & -0.00 & 0.996 \\
\hline 1.NB $\left(^{\circ}\right)$ & 32.52 & 5.61 & 34.43 & 5.38 & 50 & 6.03 & -0.25 & 0.803 \\
\hline 1-NB (mm) & 7.81 & 2.63 & 7.73 & 2.29 & 50 & 1.02 & 0.04 & 0.961 \\
\hline
\end{tabular}

* Statistically significant for $\mathrm{p}<0.05$.

Table 4 - Student's independent $t$ test by gender .Experimental group.

\begin{tabular}{|c|c|c|c|c|c|}
\hline \multirow{2}{*}{ VARIABLES } & \multicolumn{2}{|c|}{ MALE $(n=25)$} & \multicolumn{2}{|c|}{ FEMALE $(n=25)$} & \multirow{2}{*}{$\mathbf{P}$} \\
\hline & Mean & SD & Mean & SD & \\
\hline Age & 138.69 & 17.77 & 140.92 & 16.60 & 0.650 \\
\hline \multicolumn{6}{|c|}{ MAXILLARY COMPONENT } \\
\hline SNA $\left(^{\circ}\right)$ & 84.00 & 3.42 & 83.63 & 2.8 & 0.684 \\
\hline Co-A(mm) & 101.42 & 5.32 & 97.12 & 4.43 & $0.003^{*}$ \\
\hline A-Nperp (mm) & 3.36 & 3.38 & 3.88 & 2.57 & 0.541 \\
\hline \multicolumn{6}{|c|}{ MANDIBULAR COMPONENT } \\
\hline SNB $\left(^{\circ}\right)$ & 76.82 & 2.87 & 77.40 & 2.56 & 0.459 \\
\hline Co-Gn(mm) & 122.32 & 6.07 & 120.02 & 5.98 & 0.182 \\
\hline P-Nperp (mm) & -8.17 & 6.01 & -4.44 & 3.95 & $0.012^{\star}$ \\
\hline \multicolumn{6}{|c|}{ MAXILLO-MANDIBULAR RELATIONSHIP } \\
\hline ANB $\left(^{\circ}\right)$ & 7.17 & 1.94 & 6.24 & 1.35 & 0.054 \\
\hline Wits (mm) & 7.37 & 3.02 & 5.49 & 2.06 & $0.013^{*}$ \\
\hline $\mathrm{DMM}(\mathrm{mm})$ & 20.91 & 3.31 & 27.04 & 2.11 & 0.171 \\
\hline \multicolumn{6}{|c|}{ VERTICAL COMPONENT } \\
\hline SN.GoGn $\left({ }^{\circ}\right)$ & 33.32 & 4.76 & 33.37 & 4.40 & 0.965 \\
\hline HF. PM $\left(^{\circ}\right)$ & 26.30 & 4.50 & 25.71 & 3.90 & 0.628 \\
\hline $\operatorname{AFAI}(\mathrm{mm})$ & 72.34 & 3.90 & 69.59 & 5.24 & $0.039^{*}$ \\
\hline \multicolumn{6}{|c|}{ DENTOALVEOLAR COMPONENT } \\
\hline 1.NA $\left(^{\circ}\right)$ & 21.28 & 9.14 & 22.11 & 7.93 & 0.733 \\
\hline $1-\mathrm{NA}(\mathrm{mm})\left(^{\circ}\right)$ & 3.30 & 3.15 & 3.99 & 2.31 & 0.387 \\
\hline 1.NB $\left(^{\circ}\right)$ & 34.51 & 5.68 & 34.09 & 5.13 & 0.786 \\
\hline $1-\mathrm{NB}(\mathrm{mm})$ & 8.08 & 2.41 & 7.37 & 2.17 & 0.279 \\
\hline
\end{tabular}

* Statistically significant for $\mathrm{p}<0.05$. 
Table 5 - Means and standard deviations of the experimental and control groups for the assessed measures.

\begin{tabular}{|c|c|c|c|c|c|}
\hline \multirow{2}{*}{ VARIABLES } & \multicolumn{2}{|c|}{ EXPERIMENTAL GROUP } & \multicolumn{2}{|c|}{ CONTROL GROUP } & \multirow{2}{*}{$\mathbf{P}$} \\
\hline & Mean & SD & Mean & SD & \\
\hline \multicolumn{6}{|c|}{ MAXILLARY COMPONENT } \\
\hline SNA $\left({ }^{\circ}\right)$ & 83.82 & 3.11 & 82.95 & 2.96 & 0.155 \\
\hline Co-A (mm) & 99.36 & 5.33 & 92.78 & 4.19 & $0.000^{\star}$ \\
\hline A-Nperp (mm) & 3.61 & 2.99 & 0.03 & 2.35 & $0.000^{\star}$ \\
\hline \multicolumn{6}{|c|}{ MANDIBULAR COMPONENT } \\
\hline $\mathrm{SNB}\left({ }^{\circ}\right)$ & 77.10 & 2.72 & 80.25 & 2.67 & $0.000^{\star}$ \\
\hline Co-Gn (mm) & 121.22 & 6.08 & 116.57 & 5.68 & $0.000^{\star}$ \\
\hline P-Nperp (mm) & -6.38 & 5.41 & -3.55 & 4.4 & $0.005^{\star}$ \\
\hline \multicolumn{6}{|c|}{ MAXILLO-MANDIBULAR RELATIONSHIP } \\
\hline $\operatorname{ANB}\left(^{\circ}\right)$ & 6.72 & 1.73 & 2.7 & 1.94 & $0.000^{\star}$ \\
\hline Wits (mm) & 6.38 & 2.86 & -0.16 & 2.47 & $0.000^{*}$ \\
\hline $\mathrm{DMM}(\mathrm{mm})$ & 23.85 & 14.97 & 23.79 & 3.27 & 0.978 \\
\hline \multicolumn{6}{|c|}{ VERTICAL COMPONENT } \\
\hline SN.GoGn $\left({ }^{\circ}\right)$ & 33.34 & 4.55 & 31.16 & 4.4 & $0.012^{\star}$ \\
\hline HF. PM $\left({ }^{\circ}\right)$ & 26.02 & 4.19 & 23.63 & 4.05 & $0.004^{\star}$ \\
\hline AFAI (mm) & 71.02 & 4.75 & 64.3 & 4.22 & $0.000^{\star}$ \\
\hline \multicolumn{6}{|c|}{ DENTOALVEOLAR COMPONENT } \\
\hline 1.NA $\left(^{\circ}\right)$ & 21.68 & 8.51 & 25.49 & 1.69 & $0.003^{\star}$ \\
\hline 1-NA (mm) & 3.63 & 2.77 & 4.5 & 3.95 & 0.204 \\
\hline $1 . N B\left(^{\circ}\right)$ & 34.31 & 5.37 & 28.41 & 5.14 & $0.000^{\star}$ \\
\hline 1-NB (mm) & 7.74 & 2.30 & 5 & 1.8 & $0.000^{\star}$ \\
\hline
\end{tabular}

* Statistically significant for $p<0.05$.

history of respiratory disorders. Other parameters are involved, which can be investigated in future studies. In addition, ALFH suffered the greatest variation as indicated by the method error.

The cephalometric measures for the facial pattern (SN.GoGn and HF.PM) exhibited increased values. When the facial pattern was evaluated by the SN.GoGn measure it was found to be in agreement with other investigations. ${ }^{9,22}$ Contrary to the results mentioned by some authors, ${ }^{21}$ a reduction was observed in the vertical relationship between the jaws and the skull base in the Class II, Division 1 pattern. The mean value found for HF.PM was relatively high, although consistent with results found by Karlsen ${ }^{8}$ and Ngan et al. ${ }^{13}$ The prevalence of a vertical facial growth pattern is an unfavorable factor in the correction of Class II malocclusion, rendering such treatment a most daunting task. It can be inferred based on these results that the key to a successful treatment should include control of the vertical growth of the maxilla and mandible, or the use of a mechanics that does not produce excessive increments, such as extrusion of the posterior segments.

Among the dentoalveolar component values, all measures showed statistically significant differences, except for variable 1-NA. Changes observed from the evaluation of 1.NA revealed that the upper incisors were lingually inclined. Riede ${ }^{16}$ found no significant differences between patients with Class II malocclusion and normal patients when examining the axial inclination of the incisors. The upper incisors were shown to be well positioned when assessed by 1-NA. Similar findings were reported in other studies. ${ }^{4,22}$ The reduced values found for 
measure 1.NA when compared to the control group reveals lingual inclination, compensating or masking the discrepancy between the skeletal bone bases. Measure 1-NA, which checks for a possible incisor protrusion, corroborates the maxillary measurements, which indicates that the maxilla was usually well positioned anteroposteriorly and that the teeth supported by this structure were also in a good position. The buccal inclination of mandibular incisors (1.NB) found in this study was also reported by most studies in the literature., ${ }^{9,21,22}$ Protruded lower incisors (1-NB), as found in this study, were also the most common feature observed by most researchers, ${ }^{9,22}$ although some authors have argued that the lower incisors are usually well positioned. ${ }^{11,20}$

The study revealed dental compensation in the lower incisors, with all relevant measures indicating higher values in the experimental group.

\section{CONCLUSIONS}

Based on the methods employed and the results achieved, the following conclusions could be drawn regarding the structural characteristics of Class II, Division 1 malocclusion in Ceará youths:

» Overall, the maxilla exhibited good positioning, with a few protrusive cases.

» The mandible showed a clear predominance of retrusion and sagittal dimensional changes.

» The vertical dimensions of the face were increased.

» The maxillary incisors were well-positioned in their apical bases and slightly lingually inclined.

» The lower incisors were labially inclined and protrusive in relation to their apical bases.

» The existence of gender dimorphism was identified in the following measures: P-Nperp, Co-A, Wits and ALFH. 


\section{REFERENCES}

1. Acquaro JE, Vedovello SAS, Degan VV, Valdrighi HC, Vedovello Filho M, Doná CM. Alterações dentoesqueléticas da má oclusão da Classe II, 1a divisão. RGO- Rev Gaúcha Odontol. 2007;55(3):281-5.

2. Beane RA, Reimann G, Phillips C, Tulloch C. A cephalometric comparison of black open-bite subjects and black normals. Angle Orthod. 2003;73:294-300.

3. Canuto CE. Estudo comparativo entre a análise "Wits" (University of Witwatersrand) e o ângulo ANB, na avaliação cefalométrica das relações ânteroposteriores das bases apicais, em casos de oclusão normal [dissertação]. Bauru (SP): Universidade de São Paulo; 1981.

4. Carter NE. Dentofacial changes in untreated class II, division I subjects. Br J Orthod. 1987 Nov:14(4):225-34.

5. Chung C, Wong WW. Craniofacial growth in untreated skeletal Class II subjects: A longitudinal study. Am J Orthod Dentofac Ortop. 2002 Dez;122(6):619-26.

6. Downs WB. Variations in facial relationships: their significance in treatment and prognosis. Amer J Orthod. 1948;34:812-40.

7. Jacobson A. The "Wits" appraisal of jaw disharmony. Am J Orthod. 1975 Feb; 67(2):125-38

8. Karlsen AT. Craniofacial morphology in children with Angle Class II-1 malocclusion with and without deepbite. Angle Orthod. 1994;64:437- 46.

9. Maia FA. Características cefalométricas da má oclusão de Classe II, 1a divisão em brasileiros da região nordeste, em fase de dentadura mista e permanente jovem [tese de doutorado]. Bauru (SP): Universidade de São Paulo; 1993.

10. Martins MGA. Prevalência de oclusopatias e características cefalométricas e dentárias de escolares cearenses da cidade de Fortaleza [tese de doutorado]. Natal (RN): Universidade Federal do Rio Grande do Norte; 2008.

11. McNamara JA. Components of class II malocclusion in children 8-10 years of age. Angle Orthod. 1981 July;51(3):175-202.

12. McNamara JA. A method of cephalometric evaluation. Am J Orthod. 1984 Dec;86(6):449-69.

13. Ngan PW, Byczek E, Scheick J. Longitudinal evaluation of growth changes in class II division 1 subjects. Semin Orthod. 1997 Dec;3(4):222-31.

14. Proffit WR, White RP. Surgical orthodontic treatment. St. Louis (MO) : Mosby Year Book; 1991.
15. Richardson EP. Racial differences in dimensional traits of human face. Angle Orthod. 1980;50:301-10

16. Riedel RA. The relation of maxillary structures to cranium in malocclusion and in normal occlusion. Angle Orthod. 1952 July;22(3):142-5.

17. Rosemblum RE. Classe II malocclusion: mandibular retrusion or maxillary protrusion? Angle Orthod. 1995;65(1):49-62.

18. Rothstein TL. Facial morphology and growth from 10 to 14 years of age in children presenting class II, division 1 malocclusion: A comparative roentgenographic cephalometric study. Am J Orthod Dentofac Orthod. 1971;60:619-20.

19. Rothstein TL, Yoon-Tarlie C. Dental and facial skeletal characteristics and growth of males and females with Class II, Division 1 malocclusion between the ages of 10 and 14 (revisited) - Part I: Characteristics of size, form and position. Am J Orthod Dentofac Orthod. 2000;117(3):320-32.

20. Sadowsky LP, Zachrisson BU, Nanda R, Vlachos CC, Vaden JL, editores. Atualidades em Ortodontia. Porto Alegre: Premier Máxima; 1997.

21. Sidlauskas A, Svalkauskiene V, Sidlauskas M. Assessment of skeletal and dental pattern of Class II Division 1 malocclusion with relevance to clinical practice. Stomatologija. 2006;8(1):3-8

22. Santos MAC. Caracterização cefalométrica da Classe II, 1a divisão, esquelética [dissertação]. Bauru (SP): Universidade de São Paulo; 2003

23. Silva Filho OG, Bertoz FA, Capelozza Filho L. Crescimento facial espontâneo Padrão II: estudo cefalométrico longitudinal. Rev Dental Press Ortod Ortop Facial. 2009 Jan-Fev;14(1):40-6.

24. Solow B, Kreiborg S. Soft-tissue stretching: a possible control factor in craniofacial morphogenesis. Scand J Dent Rest. 1977;85:505-7.

25. Steiner CC. Cephalometrics as a clinical tool. In: Kraus BS, Riedel RA. Vistas in orthodontics. Philadelphia (PA): Lea \& Febiger; 1962. p. 131-61.

26. Urtane I, Jakobsone G, Pugaca J. Dentofacial morphology of class II division 1. Stomatologija. 2004;6(1):3-6.

27. Woodside DG. The channelization of upper and lower anterior face heights compared to population standard in males between ages 6 to 20 years. Eur Orthod. 1979;1(1):25-40 